\title{
INTERIOR DESIGN OF THE TRADITIONAL TURKISH HOUSES: EXAMPLE OF THE XIX. CENTURY HOUSES OF CYPRUS
}

\author{
Zihni TURKAN \\ Near East University \\ zihni.turkan@neu.edu.tr
}

\begin{abstract}
In Traditional Turkish Houses, the design of the floor (bottom cover), walls (side cover), the ceiling (top cover), and the furniture elements make up the design of the interior space. The concept of "sky above, earth below" in the interior space, which has begun to take shape in the history of Turks since their tent life, has defined the floor and the ceiling. Despite the simplicity of the floors, the ornamented wooden ceilings, designed meticulously, form a characteristic. The walls are fitted with shaped wooden veneer and with functional elements of need. Various shelves, niches, wardrobes, closets, and bathing cubicles take place on the walls. The fireplace also takes place among the closets. There is very little movable furniture in the rooms. The sofas, used for sitting and sleeping are platforms, made of wood and fixed on the floor. In the XIX. century Ottoman Period houses in Cyprus, floors were covered with timber, or with local marble plaques; the marble plaques providing decoration by being laid in various geometrical shapes. Walls are quite plain. Usually, veneer is not used on walls, which have niches in the thickness of the wall, and wooden shelves, stretching at the level of the top of the doors. The ornamented, wooden window frames, surrounding the windows on the walls, and ornamented lamp niches in the main- rooms, are distinctive compared to other rooms. The simplest form of the ceiling, which is more important than the floor, is the naked one. The veneered ceilings of multi-functional rooms, and the veneered ceilings of main-rooms with decorations, form the top cover. There are no fixed fittings in rooms, such as sofas, wardrobes, closets, cupboards, or bathing cubicles. The use of movable furniture is seen in the houses in Cyprus especially towards the end of the XIX. century.
\end{abstract}

Keywords: Cyprus, Traditional, Turkish House, Inner space, Design

\section{GELENEKSEL TÜRK EVLERINDE İÇ MEKÂN TASARIMI: KIBRIS XIX. YÜZYIL EVLERİ ÖRNEKLEMESİ}

\section{Öz}

Geleneksel Türk Evleri'nde döşeme (alt örtü), duvar (yan örtü), tavan (üst örtü) ve mobilya ögelerinin düzenlemeleri, iç mekân tasarımını oluşturmaktadır. Türklerin tarihindeki çadır yaşamından itibaren biçimlenmeye başlayan iç mekânda, "üstte gök, altta toprak" anlayışı, döşeme ve tavanı tanımlamıştır. Döşemenin yalınlığına karşın, oldukça özenle tasarlanan işlemeli ahşap tavanlar, karakteristik teşkil etmektedir. Duvarlar ise biçimlendirilmiş ahşap kaplamalar ve fonksiyonel gereksinim elemanları ile donatılmıştır. Çeşitli raflar, nişler, dolaplar, yüklükler ve gusülhaneler, duvarlarda yer almıştır. Ocak da dolaplar arasında bulunmaktadır. Odalarda hareketli mobilya çok azdır. Oturma ve yatma amaçlı kullanılan sedirler, ahşaptan yapılmış ve döşemeye sabitlenmiş sekilerdir. Kıbrıs'taki Osmanlı Dönemi XIX. yüzyıl evlerinde döşemeler, yerel malzeme olan mermer plaklar veya ahşaplarla kaplanmış; mermer plakların çeşitli geometrik biçimlerde dizilmesi ile de döşemeye dekor verilmiştir. Duvarlar, oldukça yalındır. Genellikle duvar kalınlığı içinde nişler ve kapı üst seviyesinde uzanan ahşap raflar bulunan duvarlarda, ahşap kaplamalar görülmemektedir. Başodaların duvarlarındaki pencereleri çerçeve içine alan işlemeli ahşap pervazlar ve süslenmiş lambalık nişleri, diğer odalara göre farklılık teşkil etmektedir. Döşemeye göre daha önemli olan tavanın en yalın hali, kaplamasız olandır. Çok amaçlı odalardaki ahşap kaplamalı tavanlar ile başodalardaki işlemeli ahşap kaplamalı tavanlar, üst örtü'yü oluşturmaktadırlar. Odalarda sedir, dolap, yüklük, gusülhane gibi sabit donatı yoktur. Kıbrıs'taki evlerde, özellikle XIX. yüzyılın sonlarında, hareketli mobilya kullanımı görülmektedir. 
Anahtar Kelimeler: Kıbrıs, Geleneksel, Türk Evi, İ̧̧ mekân, Tasarım

\section{INTRODUCTION}

Despite the many negativities since then, and all the inadequacies in preservation, XIX. century houses of the Turkish architectural works - most of them in the capital Nicosia - built during the Ottoman Period in Cyprus (1571-1878), still preserve their importance in the historical texture they take place. Built in the character of the Traditional Turkish Houses, these buildings initially were of an outer hall plan, usually two-storied, with an inner yard, inclined roofs having wide eaves, and with oriels protruding towards the street. Towards the end of the century, this plan changed into a central hall (karnıyarık=split opened aubergines) type, and the yards became smaller. Despite the simplicity of the façade, interior spaces were designed in accordance with the size of the building, and the importance of rooms, thus adding some characteristic to the rooms. Floorings, the niches on the walls, shelves, cornices, interior wall windows, and ceilings of the XIX. Century houses, built by using traditional materials (stone, earth, wood), make up the interior space design elements. The special arrangements of these elements take place in the plain planning organization of the houses as functional and visual acquisitions. It is aimed to document common characteristic interior space arrangements of the XIX. century houses of Cyprus, which fall into the term Traditional Turkish House, through research and field studies, thus shedding light on future studies and researches.

\section{INTERIOR DESIGN ELEMENTS OF THE XIX. CENTURY HOUSES OF CYPRUS}

Floors: The floors, named "bottom cover" in the Traditional Turkish Houses, have been of the interior space formation elements with the concept of "sky above, earth below" (Küçükerman, 1991:145), since the nomadic tent life of Turks in Central Asia. Floors, which were used multi-functionally (sitting, sleeping, working) by spreading reed mats, rugs, carpets, or felt mats, were continued to be used in houses in permanent settlements, by spreading cover materials on the compressed earth (Küçükerman, 1991: 145). Later, stone and mostly wooden materials were used to cover floors, depending on the economic position of the house-owners, and on the materials available in the geography that houses were built. Platforms were made in places to create sofas for sitting purposes.

The flooring materials in the XIX. century houses in Cyprus are generally the local marble plaques, which have not completed their chemical formation yet and sometimes, wooden materials. The marble plaques, taken from quarries and cut $40 \times 40 \times 1 \mathrm{~cm}$ in size are placed on compressed earth on the ground floors, and on compressed earth spread over reed mats, which are placed on wooden beams (Anonymous, 1995:34). In multi-purpose rooms, the flooring is completed with reed mats, rugs, or carpets. The floors of rooms and sofas were made by lining square-formed marble plaques using the semi-sliding method or mostly by laying one row of marble plaques parallel to the walls, creating a frame, and placing other plaques diagonally in the center to create a décor (Figure 1). The main-room floors are shaped in accordance with the form of the room. In rectangular rooms, besides the straight lines on the sides, another straight line stretching horizontally in the center created a square shape in one part of the main room. In square-shaped main rooms, besides the style of one straight line on the sides and diagonal in the center, marble plaques were laid in different geometrical shapes to form a central ornament (Figure 2).

In wood covered floors, the wooden planks are laid parallel to the long side of the room and oiled for protection. 


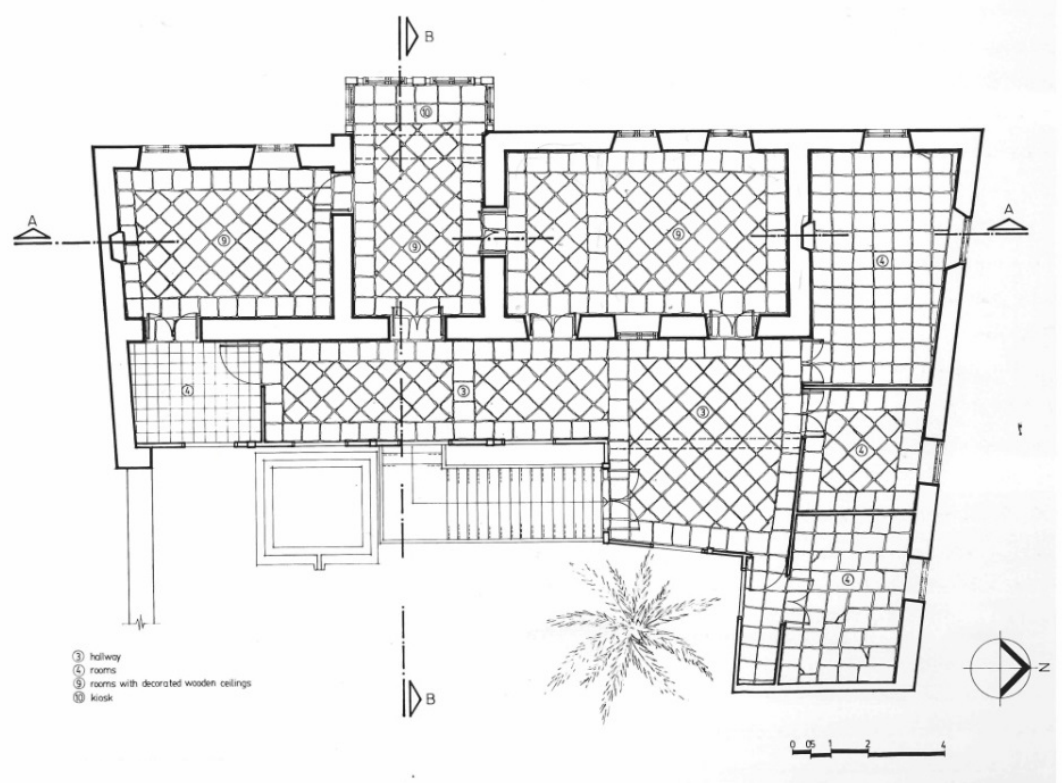

Figure 1. Floor covering by local marble plaques (Anonymous, 1995)

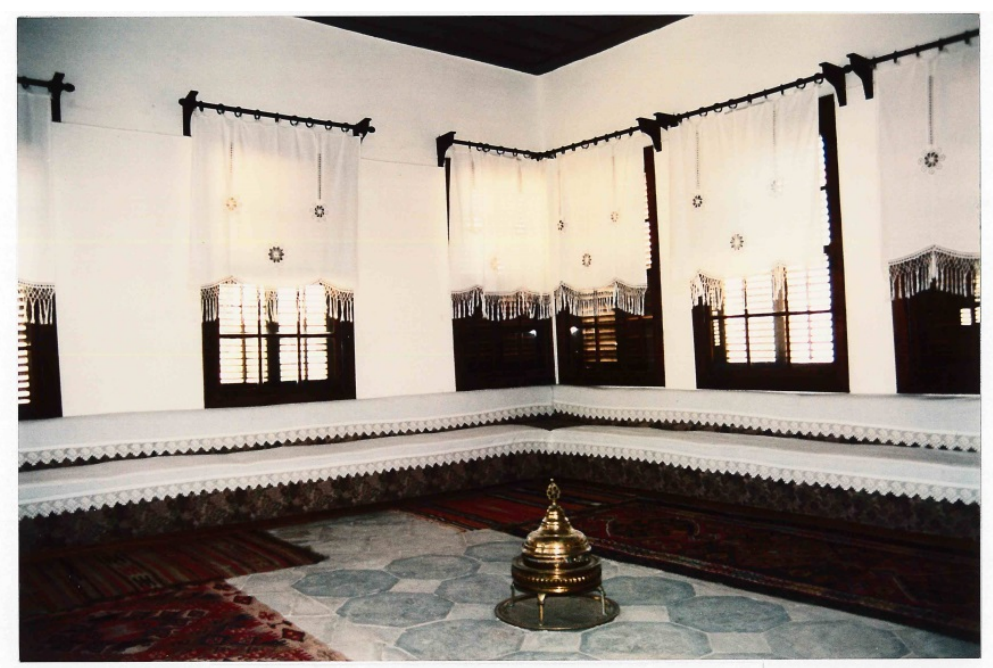

Figure 2. Main-room floor covering (By Author)

Walls: The walls (side cover) of the Traditional Turkish Houses are covered with wooden materials up to the top of the windows - a height reachable by hand $-(2.20 \mathrm{~m}$.), decorated with many functional elements, and the wood ornamented with various engravings, thus creating internal space richness (Bektaş, 1996: 110). The niches, initially created simply by making use of wall thickness, were used open or with covers, and later on they were made from wood in various geometrical shapes and for different functions. Wooden cornices, extending continuously at the level of the top of the windows, and all over the interior facets of the room, were designed as shelves and used for the display of various containers or decorative objects. Closets, in which mattresses, quilts, pillows were kept, cupboards for all sorts of goods, and bathing cubicles, all made of wood, took place in the walls of multi-functional rooms (Eldem, 1987:80; Günay, 1989: 238; Kuban, 1995: 117, 118).

The fire place, placed in the middle of the tent in the nomadic life, and used for multiple functions such as heating, and cooking, was drawn to a side of the room and placed on the facet of the wall (Dağl1, 1999:46; Eldem, 1987: 66; Turkan, 2007: 74). Rooms without a fire place, a brazier was used for heating (İmamoğlu, 1992: 83). In rooms with frequent and many windows, the wide, wooden frames were joined for continuity, and placed around the windows to form a frame. Walls in main rooms were decorated more elaborately compared to other rooms. The side cover was enriched with lamp niches, decorated with various motifs, and with lamp/plant stand niches (Günay, 1998: 239; 
Küçükerman, 1995: 135). Walls of the XIX. century houses of Cyprus are quite plain, compared to the typical wall designs of the Traditional Turkish House. No wooden cover is observed on the facets of walls with white gypsum plaster. In some of the rooms, there are rectangular niches, placed vertically within the wall thickness. Wooden shelves are placed in the niches, and some have covers with glass. Smaller niches can be seen in some rooms, placed just above these niches (Figure 3). Cylindrical niches of semi-circular plan are found in main rooms. These niches with arches, are made within the wall thickness and decorated with wooden ornaments, or are made completely of wood and ornamented with various figures. Besides their functions as lamp stands or plant stands, these niches add visual richness to the special design of the main rooms (Figure $4 a, 4 b, 4 c)$. Generally, there are no fire places in the rooms of houses in Cyprus. It was sufficient to heat rooms with a brazier placed in the middle of the room, due to climatic factors. Wooden shelves stretching at the top level of windows, while assuming the function of displaying various objects depending on the use of the room, also make up cornices for the windows with their bottom parts. The wide wooden cornices of windows, mostly in main rooms and in projecting rooms, are with profiles and they extend horizontally in a continuous fashion, creating a frame around the windows. There are wooden grids designed and shaped like small squares in windows between rooms and in those opening from the rooms into the hall, for preventing vision and for safety reasons (Figure 5). In the rooms of houses in Cyprus, there is nothing fixed in the walls, such as wardrobes, closets and bathing cubicles. It is presumed that bathing took place in the bath section (hamam) of the houses.

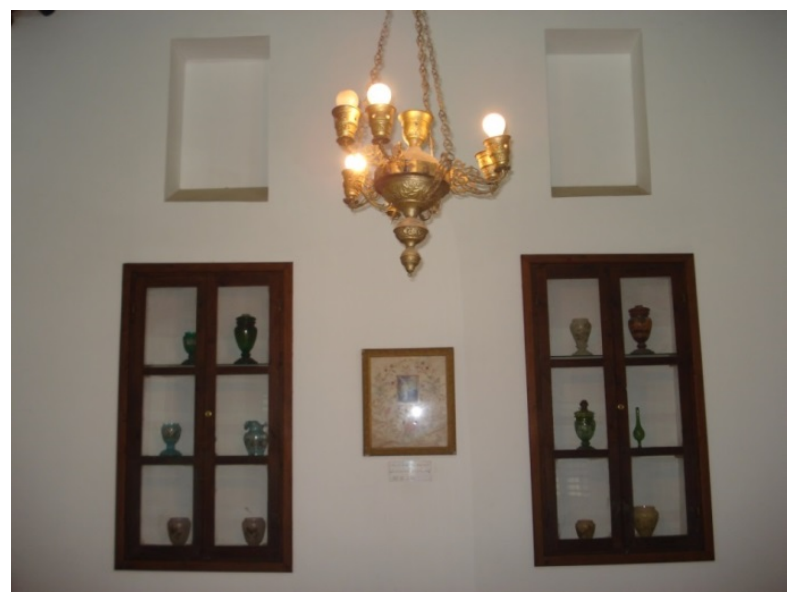

Figure 3. Wall Niches in the Eaved House - Nicosia (By Author)

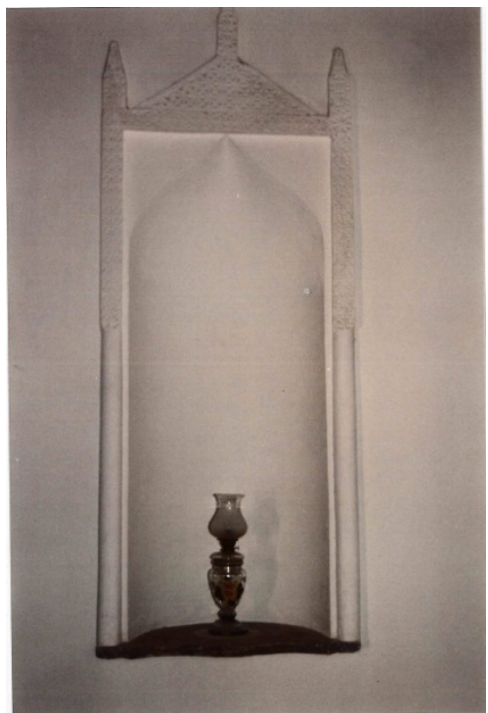

Figure 4a. Lamp-niche in the Eaved House (By Author)

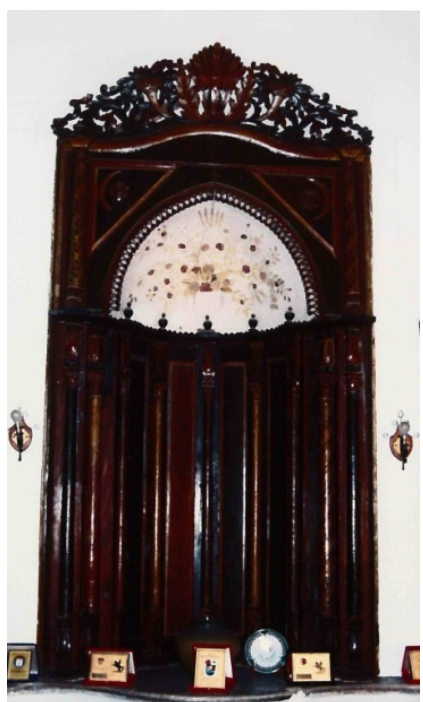

Figure 4b. Lamp-niche in the Kadı Menteşoğlu Mansion (By Author) 


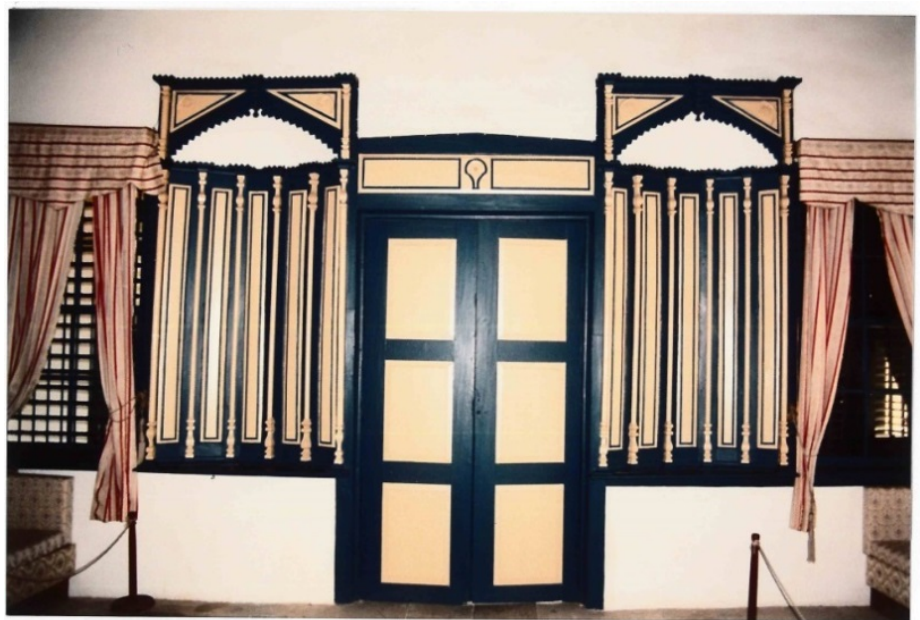

Figure 4c. Lamp-niche in the Derviş Paşa Mansion - Nicosia (By Author)

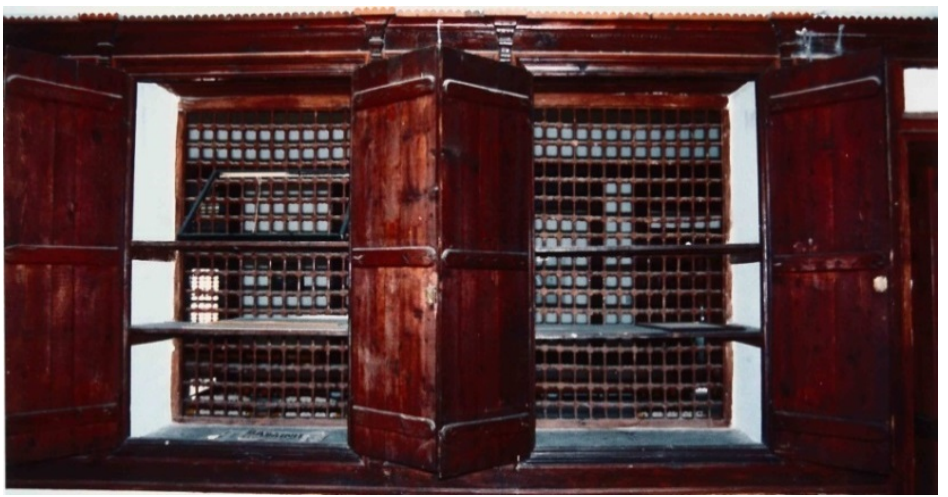

Figure 5. Window-railing (By Author)

Ceilings: Ceilings, which are the top cover of the Traditional Turkish Houses, earned importance among interior space elements with their elaborately created arrangements (Kuban, 1995: 119; Küçükerman, 1991: 159, 160). In the simplest rooms, the undersides of the ceiling beams were left without any kind of cover. The widest type of ceiling is making the underside of the wooden beams covered with wooden material. The simplest covered ceilings have borders of profiled wooden staves. The wood is protected with paint or varnish. This method is seen in multi-functional rooms of the houses (Küçükerman, 1995: 130, 131). Decorated ceilings are designed to form squares laid diagonally, using thin wooden staves. The commonest type in the Classical Ottoman style is ceilings designed by making triangles and hexagons with thin wooden staves (Bektaş, 1996: 56). Intensely decorated ceilings, especially found in main-rooms, enrich and complete the interior space richness on the floor and the walls. The decoration is strengthened with a decoration element created in the middle of the ceilings and named the central ornament. Designed in various geometrical shapes, the central ornaments are created with woodcarvings (Günay, 1989: 257).

Ceilings in the XIX. century houses in Cyprus also carry the features of the character of Traditional Turkish House. The simplest look of the ceilings is the uncovered type, where the ceiling structure is visible. Wooden beams, usually cylindrical but sometimes rectangular shaped, and standing on the walls of the rooms are seen in these ceilings, with straw mats made of canes placed on them (Figure 6). In places with long spans, the spans are passed through with pointed arches made of cut stone, with rectangular shaped wooden main beams or with wooden trusses, and the cylindrical beams are carried by these main carriers. The wooden main beams and wooden trusses are supported by wooden corbels on the wall edges, shaped with C-S scrolls (curves) (Figure 7). In the undecorated wood covered ceilings, the joints of wood stretching side by side are filled with staves, and encircled with wooden borders. In the Turkish Houses in Cyprus, especially in main-rooms and projected rooms, the ceilings 
are wood covered and ornamented (Anonymous, 1982: 32; Turkan, 2010: 283). Because of the importance of these rooms, the ceiling is also made special in space designs. The ceiling is decorated with works using thin profiled wooden staves to make various geometrical shapes. A central ornament is place in the middle, again made of wood engravings and works (Figure 8a, 8b, 8c). The ceilings are also encircled with engraved wooden sills. Ceilings of rectangular planned rooms are divided into two using wooden sills, creating one of is square shaped section. The woods in the ceilings are protected by varnish or paint.

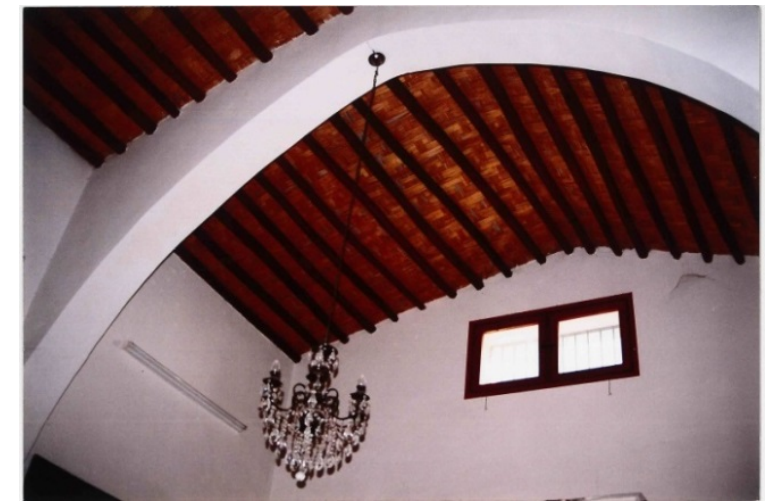

Figure 6. Ceiling without cover (By Author)

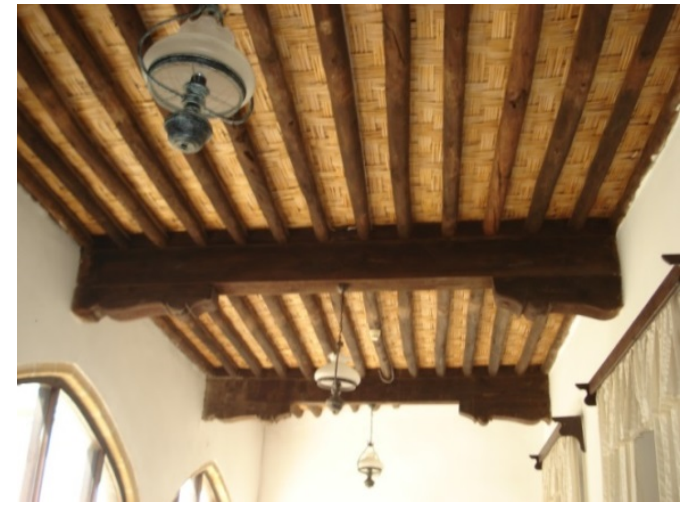

Figure 7. Ceiling with wooden main beams (By Author)

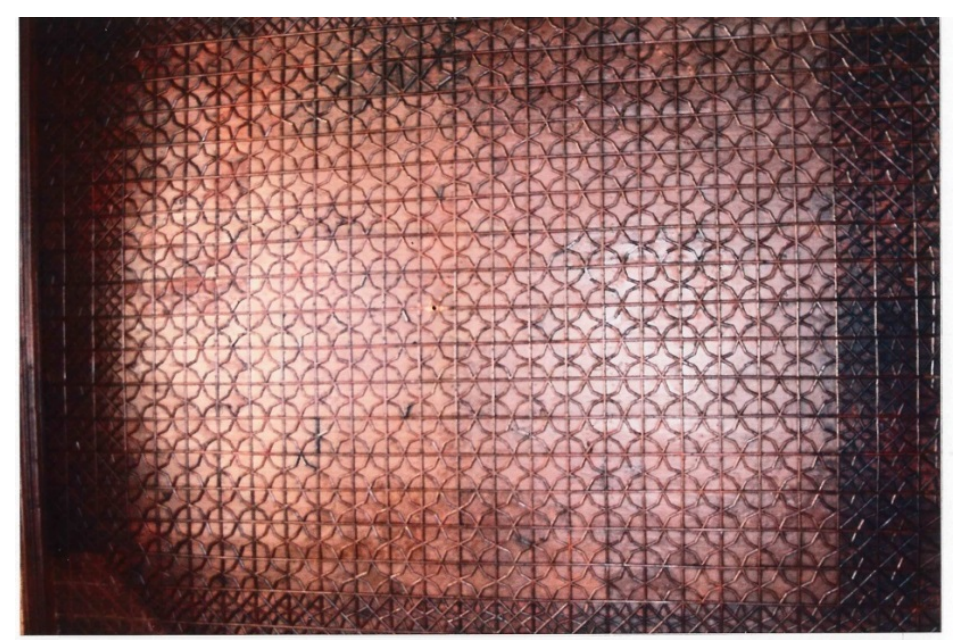

Figure 8a. Ceiling of projected room of the Ottoman Mansion - Nicosia (By Author)

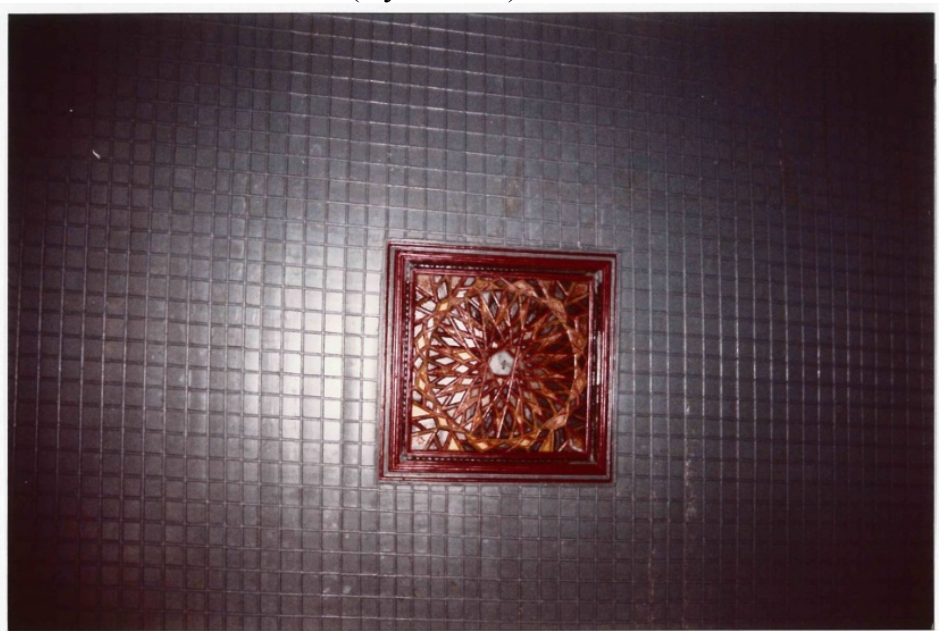

Figure 8b. Ceiling of main-room of the Kadı Menteşoğlu Mansion - Nicosia (By Author) 


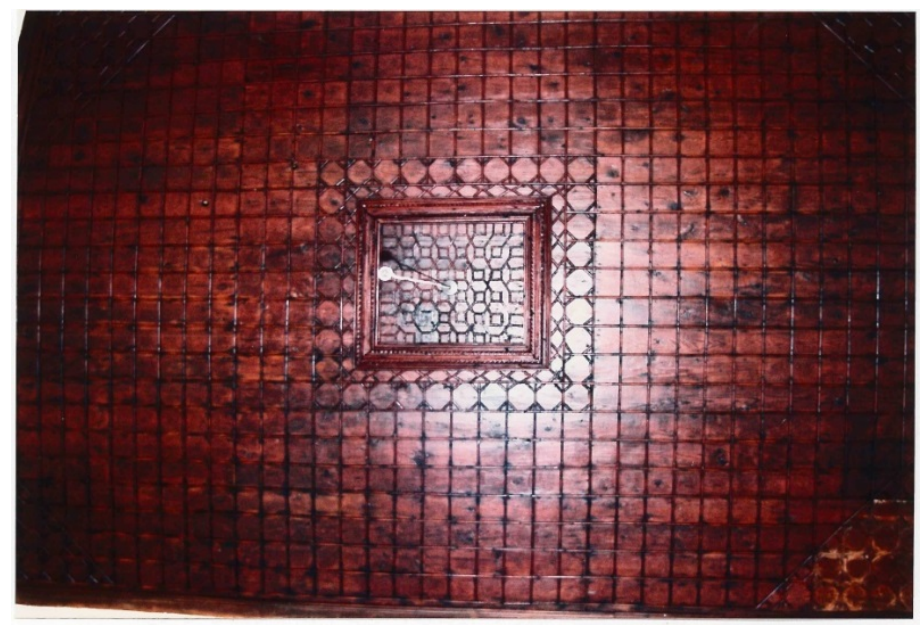

Figure 8c. Ornamented ceiling of the Ottoman Mansion - Nicosia (By Author)

Furniture: There is very little furniture in the Traditional Turkish Houses. The multi-functional fittings seen in the tents of nomadic life and serving for both day and night use, are seen in the houses of permanent settlement life as the few fittings in multi-functional rooms (Bektaş, 1996: 110; Günay, 1998: 245). The wooden platforms found in some of the rooms and in the hall, and fixed to the floor, make up the sofas used for sitting and sleeping (Günay, 1998: 25; Küçükerman, 1991: 149). The wardrobes, closets, shelves, and bathing cubicles in the rooms are fixed fittings, made of wood.

In the XIX. century Turkish Houses of Cyprus, fixed fittings such as sofa platforms, wardrobes, closets, and bathing cubicles are not seen. Mobile furniture, such as divans, beds, chests, chairs, and tables are used especially in the second half of the XIX. century (Figure 9a, 9b). Chests of various sizes, carved out of wood and shaped, wooden divans, chairs with wooden skeleton, completed with woven straw, wooden tables, and beds made of iron or brass are valued today as authentic pieces of furniture.

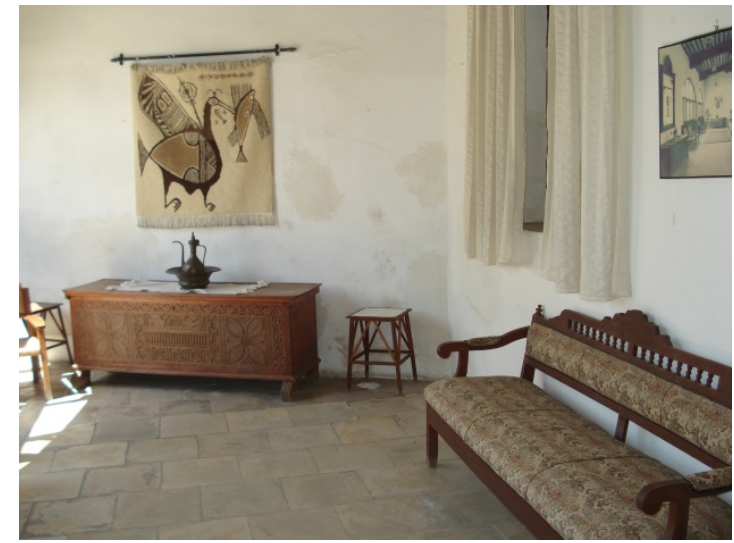

Figure 9a. Furniture in the Eaved House-Nicosia (By Author)

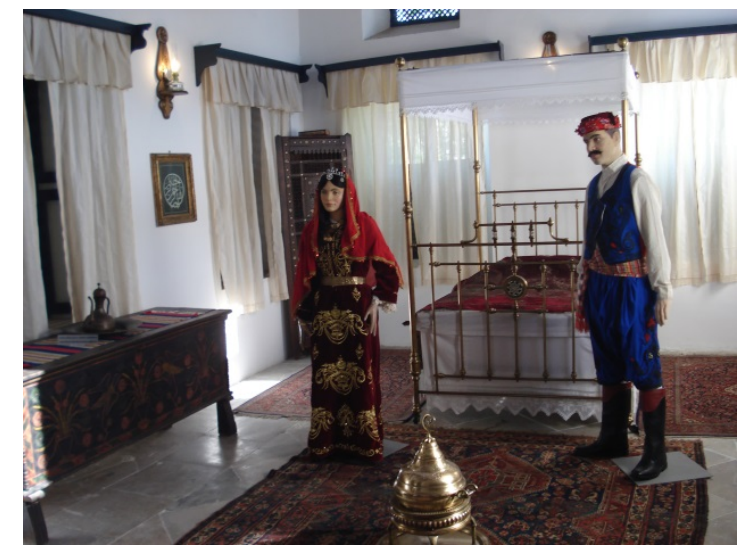

Figure 9b. Furniture in the Derviş Paşa Mansion-Nicosia (By Author) 


\section{CONCLUSION}

XIX. century houses, built in Cyprus during the Ottoman Period, take place mostly in Nicosia in the walled city, as examples of the Traditional Turkish House concept. The oldest ones being of the outdoor hall plan type, interior space designs of these houses have common characteristics with those of the same period found in other countries. Floors, covered with wood and local material marble plaques, make the bottom cover. The marble plaques are laid in various designs such as half sliding, straight, or diagonal, and different geometrical shapes are created to increase the décor of the floor, especially in main-rooms.

Walls are plain. In some rooms, there are vertical, rectangular niches, made by using the thickness of the wall. The cylindrical niches, covered with marble on the inside, and decorated with plaster or wooden material, found in the center of the walls in main-rooms, are used as lamp stands or flower stands. The profiled, wooden cornices, stretching along at the top level of doors and windows, add to the visual richness of the interior. Windows on the interior walls, there are wooden bars, besides glass sashes. Designed to form small square sections, these bars are for blocking the view as well as for safety. There are no fixed fittings on the walls of the XIX. century houses in Cyprus.

The simplest state of the ceilings is of uncovered ceilings where the structure is visible. The main wooden beams and trusses found in the long span ceilings, where the wooden runners are in the open, are supported with C-S curved wooden corbels.

On wood covered ceilings, the joints of woods placed side by side are covered with profiled staves, and surrounded by ornamented wooden cornices. Especially in main-rooms and in projected rooms, the wooden cover is decorated with various geometrical shapes, made by thin wooden staves. The ceilings of rectangular planned rooms are divided into two, creating one of is square shaped section and a central ornament is placed on the middle of square section, made of ornamented wood. Fixed furniture is not seen in houses. Movable furniture was used, changing places in the room, depending on various functions.

Based on research and investigations, during the XIX. century, when the characteristics of the Traditional Turkish House became quite explicit, the interior designs of houses built in Cyprus show a similarity in general with the interior designs of Turkish Houses in other geographical areas. However, the interiors of the XIX. century houses of Cyprus, mostly of medium size and modest standards were designed with a rather simple conception. The effects of different cultures throughout the history of the island on the living culture of its people are also reflected in the interior designs of the houses.

\section{REFERENCES}

Anonymous (1982), Kıbrıs'ta Türk Eserleri, Lefkoşa: K.T.F.D. Eğitim, Gençlik, Kültür ve Spor Bakanlı̆̆ Eski Eserler ve Müzeler Dairesi Müdürlüğ̈̈ Yayını.

Anonymous (1995), Twelve Traditional Cyprus Houses, Nicosia: Published by UNCHR

Bektaş, C. (1996), Türk Evi, İstanbul: Yapı Kredi Yayınları.

Dağll, U. U. (1999), Kıbrıs Sokaklarında Mimariye Yaşama ve Çevreye Dair, Lefkoşa: Işılk Kitabevi Yayinlart.

Eldem, S. H. (1987), Türk Evi Osmanlı Dönemi III, İstanbul: Türkiye Anıt Çevre Turizm

Değerlerini Koruma Vakfi Yayını.

Günay, R. (1989), Geleneksel Safranbolu Evleri ve Oluşumu, Ankara: Kültür Bakanlığı Yayınları. Günay, R. (1998), Türk Ev Geleneği ve Safranbolu Evleri, İstanbul: Yapı-Endüstri Merkezi Yay. Imamoğlu, V. (1992), Geleneksel Kayseri Evleri, Ankara: Türkiye Halk Bankası Yayını. Kuban, D. (1995), Türk Hayat'lı Evi, İstanbul: T.C. Ziraat Bankası Kültür Yayını. Küçükerman, Ö. (1991), Kendi Mekânının Arayışı İçinde Türk Evi, İstanbul: Türkiye Turing ve Otomobil Kurumu Yayını.

Küçükerman, Ö. (1995), Anadolu Mirasında Türk Evleri, İstanbul: T.C. Kültür Bakanllğg Yayını. Turkan, Z. (2007), “Türk Evi Dünden Bugüne”, Tasarım S:177. İstanbul: 72-75. 
The Turkish Online Journal of Design, Art and Communication - TOJDAC July 2017 Volume 7 Issue 3

Turkan, Z. (2010), “Kıbrıs'ta Türk Mimarisi Lefkoşa'da 19. Yüzyll Evleri ve Tarihi Sokak Dokusu”. Türk Dünyası Mimarlı ve Şehircilik Kurultay 2010 Astana Bildiriler Kitabı III, Ankara: 279-286. Türkiye Belediyeler Birliği Yayını. 